\title{
Cr(VI) sorption/desorption on untreated and mussel-shell-treated soil materials: fractionation and effects of $\mathrm{pH}$ and chromium concentration
}

\author{
M. Otero ${ }^{1}$, L. Cutillas-Barreiro ${ }^{2}$, J. C. Nóvoa-Muñoz ${ }^{2}$, M. Arias-Estévez ${ }^{2}$, M. J. Fernández-Sanjurjo ${ }^{1}$, \\ E. Álvarez-Rodríguez ${ }^{1}$, and A. Núñez-Delgado ${ }^{1}$ \\ ${ }^{1}$ Department of Soil Science and Agricultural Chemistry, Engineering Polytechnic School, University of Santiago de \\ Compostela, 27002 Lugo, Spain \\ ${ }^{2}$ Department of Plant Biology and Soil Science, Faculty of Sciences, University of Vigo, 32004 Ourense, Spain
}

Correspondence to: A. Núñez-Delgado (avelino.nunez@usc.es)

Received: 24 November 2014 - Published in Solid Earth Discuss.: 18 December 2014

Revised: 13 March 2015 - Accepted: 20 March 2015 - Published: 2 April 2015

\begin{abstract}
We used batch-type experiments to study $\mathrm{Cr}(\mathrm{VI})$ sorption/desorption on granitic material, forest soil, pyritic material, mussel shell, and on forest soil and granitic material amended with $12 \mathrm{tha}^{-1}\left(1.2 \mathrm{~kg} \mathrm{~m}^{-2}\right)$ shell, considering the effects of varying $\mathrm{Cr}(\mathrm{VI})$ concentration and $\mathrm{pH}$. Sequential extractions were carried out to fractionate adsorbed $\mathrm{Cr}(\mathrm{VI})$ and to determine the stability of $\mathrm{Cr}(\mathrm{VI})$ retention. The pyritic material had the highest $\mathrm{Cr}(\mathrm{VI})$ retention capacity, whereas the granitic material showed the lowest retention potential. When high $\mathrm{Cr}$ concentrations were added, some saturation of the adsorbent surfaces became apparent, but $\mathrm{Cr}$ release remained low. The highest $\mathrm{Cr}$ retention was achieved at a very acid $\mathrm{pH}$ value, with release progressively increasing as a function of increasing $\mathrm{pH}$. The amendment with $12 \mathrm{tha}^{-1}$ mussel shell did not cause marked changes in $\mathrm{Cr}(\mathrm{VI})$ retention. Sorption data were satisfactory adjusted to the Freundlich model. Regarding $\mathrm{Cr}(\mathrm{VI})$ fractionation, the soluble fraction (weakly bound) was dominant in mussel shell and in the unamended and amended granitic material, whereas more stable fractions dominated in the pyritic material (residual fraction) and in the forest soil (oxidizable fraction). In conclusion, the pyritic material presented the highest $\mathrm{Cr}(\mathrm{VI})$ retention capacity, while the retention was low and weak on the granitic material; mussel shell was not characterized by a marked $\mathrm{Cr}(\mathrm{VI})$ retention potential, and it did not cause remarkable increase in $\mathrm{Cr}(\mathrm{VI})$ retention when used to amend the granitic material or the forest soil.
\end{abstract}

\section{Introduction}

Mining, industrial, and agricultural activities are the main sources of chromium pollution affecting the environment, notably the water and soil compartments (Alves et al., 1993; Di et al., 2006). $\mathrm{Cr}$ (III) is the chemically most stable form of chromium, whereas $\mathrm{Cr}(\mathrm{VI})$ is highly toxic and more easily mobilized. Mobilization of $\mathrm{Cr}(\mathrm{VI})$, and then risks of water pollution and even of transfer to the food chain, are strongly related to retention processes affecting the pollutant (Lilli et al., 2015).

Different bio-adsorbents have been tried to remove $\mathrm{Cr}(\mathrm{VI})$ from polluted environments, as was the case for some microorganisms and other natural sorbents (Schiever and Volesky, 1995). Schmuhl et al. (2001) found high $\mathrm{Cr}(\mathrm{VI})$ sorption on chitosan, with best results at $\mathrm{pH} 5$. Blázquez et al. (2009) obtained $\mathrm{Cr}(\mathrm{VI})$ sorption $>80 \%$ on olive waste at $\mathrm{pH}<2$, although sorption clearly diminished when $\mathrm{pH}$ increased. Good $\mathrm{Cr}(\mathrm{VI})$ sorption results were achieved using algae and cyanobacteria (Park et al., 2006; Gupta and Rastogi, 2008a, b), as well as using waste from the coffee and tea industries (Fiol et al., 2008; Duran et al., 2011).

Globally, it is necessary to increase the knowledge on $\mathrm{Cr}(\mathrm{VI})$ retention processes by sorbent materials. In this way, Fernández-Pazos et al. (2013) studied quantitative and kinetic aspects regarding $\mathrm{Cr}(\mathrm{VI})$ sorption/desorption on various solid media (fine and coarse mussel shell, unamended and mussel-shell-amended forest and vineyard soils, slateprocessing fines and pyritic material). In addition to the ki- 
netic characterization, it would be interesting to elucidate complementary aspects, such as the effects on $\mathrm{Cr}(\mathrm{VI})$ retention caused by changing $\mathrm{pH}$, or the fractions where the retained $\mathrm{Cr}(\mathrm{VI})$ was bound, which can aid in estimating the degree of stability of that retention.

Therefore, the main objectives of this work are (a) to determine $\mathrm{Cr}(\mathrm{VI})$ sorption/desorption when different $\mathrm{Cr}(\mathrm{VI})$ concentrations are added to a granitic material, a forest soil, a pyritic material, and fine mussel shell, as well as to the granitic material and the forest soil amended with $12 \mathrm{tha}^{-1}$ $\left(1.2 \mathrm{~kg} \mathrm{~m}^{-2}\right)$ fine mussel shell; (b) to elucidate the influence of varying $\mathrm{pH}$ as regards $\mathrm{Cr}(\mathrm{VI})$ sorption on such materials; and, finally, (c) to determine the fractions where $\mathrm{Cr}(\mathrm{VI})$ is retained in the various solid materials investigated, which affect $\mathrm{Cr}(\mathrm{VI})$ release and thus overall risks of pollution.

\section{Materials and methods}

\subsection{Materials}

The materials used in this study are indicated in Table 1. The granitic material (GM) was sampled in Santa Cristina (Ribadavia, Ourense Province, Spain) and resulted from the evolution of a rocky substrate, similar to a $\mathrm{C}$ horizon, nowadays exposed to the atmosphere after the elimination of the upper horizons, then needing organic matter and nutrients to be restored, as happens with granitic mine spoils. The forest soil (FS) was an A horizon, with dominance of Eucalyptus globulus as tree species, and it was sampled in the vicinity of the Alcoa aluminum factory (San Cibrao, Lugo Province, Spain). The pyritic material (PM) was from a copper mine spoil (Touro, A Coruña Province, Spain). The mussel shell $(\mathrm{Sh})(<1 \mathrm{~mm})$ was from the factory Abonomar S.L. (Illa de Arousa, Pontevedra Province, Spain). The two mixtures (granitic material $+12 \mathrm{tha}^{-1}$ mussel shell $-\mathrm{GM}+\mathrm{Sh}$, and forest soil $+12 \mathrm{tha}^{-1}$ mussel shell $-\mathrm{FS}+\mathrm{Sh}$ ) were shaken for $48 \mathrm{~h}$ to achieve homogenization. The unity tha ${ }^{-1}$ is widely used, but note that the dose $12 \mathrm{tha}^{-1}$ mussel shell is equivalent to $1.2 \mathrm{~kg} \mathrm{~m}^{-2}$. The FS, PM, and Sh here used were previously characterized by Fernández-Pazos et al. (2013) in a study focusing on kinetics of $\mathrm{Cr}(\mathrm{VI})$ retention, as well as in evaluating the effects of adding different concentrations of the pollutant to various sorbent materials. Fernández-Pazos et al. (2013) found that the amendment of pyritic material with mussel shell had no positive effect on $\mathrm{Cr}(\mathrm{VI})$ retention, so this combination was discarded in the present study.

FS, PM, and GM were sampled in a zigzag manner $(20 \mathrm{~cm}$ depth), with 10 subsamples taken to perform each of the composite FS, PM, and GM final samples. These samples were transported to the laboratory to be air-dried and sieved through $2 \mathrm{~mm}$. Finally, chemical determinations and trials were carried out on the $<2 \mathrm{~mm}$ fraction.
Table 1. Materials investigated and abbreviations used to designate them.

\begin{tabular}{l|l}
\hline Granitic material & GM \\
Forest soil & FS \\
Pyritic material & PM \\
Mussel shell & Sh \\
Granitic material $+12 \mathrm{tha}^{-1}$ mussel shell & $\mathrm{GM}+\mathrm{Sh}$ \\
Forest soil $+12 \mathrm{tha}^{-1}$ mussel shell & FS $+\mathrm{Sh}$ \\
\hline
\end{tabular}

\subsection{Methods}

\subsubsection{Characterization of the solid materials used}

The particle-size distribution of the materials was determined by using the Robinson pipette procedure. A pH meter (model 2001, Crison, Spain) was used to measure $\mathrm{pH}$ in water and in $\mathrm{KCl}$ (solid: liquid ratio $1: 2.5$ ). Total $\mathrm{C}$ and $\mathrm{N}$ were quantified by means of the elemental Tru Spec CHNS autoanalyzer (LECO, USA). Available P was determined according to Olsen and Sommers (1982). The exchangeable cations were displaced using $\mathrm{NH}_{4} \mathrm{Cl} 1 \mathrm{M}$ solution, then quantifying $\mathrm{Ca}, \mathrm{Mg}$, and $\mathrm{Al}$ by atomic absorption spectroscopy, and $\mathrm{Na}$ and $\mathrm{K}$ by atomic emission spectroscopy (AAnalyst 200, Perkin Elmer, USA); the effective cationic exchange capacity (eCEC) was calculated as the sum of all these cations (Kamprath, 1970). Total concentrations of $\mathrm{Na}, \mathrm{K}, \mathrm{Ca}, \mathrm{Mg}, \mathrm{Al}, \mathrm{Fe}$, and $\mathrm{Mn}$, as well as $\mathrm{As}, \mathrm{Cd}, \mathrm{Co}, \mathrm{Cr}, \mathrm{Cu}, \mathrm{Ni}$, and $\mathrm{Zn}$, were determined by means of inductively coupled plasma (ICP)mass spectrometry (820-NS, Varian, USA), after nitric acid (65\%) microwave assisted digestion. Different selective solutions were used to obtain the following $\mathrm{Al}$ and $\mathrm{Fe}$ fractions (Álvarez et al., 2013): total non-crystalline $\mathrm{Al}$ and $\mathrm{Fe}$ $\left(\mathrm{Al}_{\mathrm{o}}, \mathrm{Fe}_{\mathrm{o}}\right)$, total $\mathrm{Al}$ and $\mathrm{Fe}$ bound to organic matter $\left(\mathrm{Al}_{\mathrm{p}}\right.$, $\left.\mathrm{Fe}_{\mathrm{p}}\right)$, non-crystalline inorganic $\mathrm{Al}$ and $\mathrm{Fe}\left(\mathrm{Al}_{\mathrm{op}}, \mathrm{Fe}_{\mathrm{op}}\right), \mathrm{Al}$ bound to organic matter in medium- and low-stability complexes $\left(\mathrm{Al}_{\mathrm{cu}}\right), \mathrm{Al}$ bound to organic matter in high-stability complexes $\left(\mathrm{Al}_{\mathrm{pcu}}\right), \mathrm{Al}$ bound to organic matter in mediumstability complexes $\left(\mathrm{Al}_{\text {cula }}\right)$, and $\mathrm{Al}$ bound to organic matter in low-stability complexes $\left(\mathrm{Al}_{\text {la }}\right)$.

\subsubsection{Sorption/desorption when different $\mathrm{Cr}(\mathrm{VI})$ concentrations are added}

$\mathrm{Cr}(\mathrm{VI})$ sorption and desorption as a function of the added concentration of the pollutant were studied as per Arnesen and Krogstrad (1998).

The adsorbents used were the materials previously mentioned (Table 1). Fernández-Pazos et al. (2013) found that the amendment of pyritic material with mussel shell had no positive effect on $\mathrm{Cr}(\mathrm{VI})$ retention, so this combination was discarded in the present study.

As in Fernández-Pazos et al. (2013), $3 \mathrm{~g}$ of each solid sample was added with $30 \mathrm{~mL} \mathrm{NaNO}{ }_{3} 0.01 \mathrm{M}$ dissolutions containing $0,0.5,5,10,25,50$, or $100 \mathrm{mg} \mathrm{L}^{-1}$ of $\mathrm{Cr}(\mathrm{VI})$, 
prepared from analytical-grade $\mathrm{K}_{2} \mathrm{Cr}_{2} \mathrm{O}_{7}$ (Panreac, Spain). The resulting suspensions were shaken for $24 \mathrm{~h}$, centrifuged at $4000 \mathrm{rpm}(6167 \times \mathrm{g})$ for $15 \mathrm{~min}$, and finally filtered using acid-washed paper. In the equilibrium dissolutions, $\mathrm{pH}$ was measured using a glass electrode (Crison, Spain), dissolved organic carbon (DOC) was determined by means of UV-visible spectroscopy (UV-1201, Shimadzu, Japan), and $\mathrm{Cr}$ (VI) using ICP-mass spectrometry (Varian 800-NS, USA). All trials were performed by triplicate.

Immediately after finalizing each batch experiment corresponding to the sorption trials, each sample was added with $30 \mathrm{~mL}$ of $\mathrm{NaNO}_{3} \quad 0.01 \mathrm{M}$ solution to desorb $\mathrm{Cr}(\mathrm{VI})$ and then shaken for $24 \mathrm{~h}$, centrifuged, and filtered as in the sorption trials (Arnesen and Krogstad, 1998). Desorbed Cr(VI), DOC, and $\mathrm{pH}$ were determined in all samples.

\subsection{3 $\mathrm{Cr}$ (VI) sorption/desorption as a function of $\mathrm{pH}$}

To study sorption, triplicate samples ( $1 \mathrm{~g}$ each) of the sorbent materials (Table 1) were added with $10 \mathrm{~mL}$ of solutions containing $5 \mathrm{mg} \mathrm{L}^{-1} \mathrm{Cr}(\mathrm{VI})$ and different concentrations of $\mathrm{HNO}_{3}(0.0025,0.0038,0.005,0.0075 \mathrm{M})$ or $\mathrm{NaOH}(0.0025$, $0.0038,0.005,0.0075 \mathrm{M}$ ), also including $\mathrm{NaNO}_{3} 0.01 \mathrm{M}$ as a background electrolyte. Control samples were constituted by each of the solid materials added with $10 \mathrm{~mL}$ of solutions containing $\mathrm{NaNO}_{3} 0.01 \mathrm{M}$ and $5 \mathrm{mg} \mathrm{L}^{-1} \mathrm{Cr}(\mathrm{VI})$, but without $\mathrm{HNO}_{3}$ or $\mathrm{NaOH}$. All samples were shaken for $24 \mathrm{~h}$, centrifuged for $15 \mathrm{~min}$ at $4000 \mathrm{rpm}(6167 \times \mathrm{g})$, and filtered through acid-washed paper. The resulting liquid was analyzed for $\mathrm{pH}$, DOC, and $\mathrm{Cr}(\mathrm{VI})$. Adsorbed $\mathrm{Cr}(\mathrm{VI})$ was calculated as the difference between added $\mathrm{Cr}(\mathrm{VI})$ concentration and that remaining in the equilibrium solution.

Desorption was studied using triplicate samples (1 g each) of the same solid materials as in the sorption trials, which were added with $10 \mathrm{~mL}$ of solutions containing $100 \mathrm{mg} \mathrm{L}^{-1}$ $\mathrm{Cr}(\mathrm{VI})$, also including $\mathrm{NaNO}_{3} 0.01 \mathrm{M}$ as a background electrolyte. All samples were shaken for $24 \mathrm{~h}$, centrifuged for $15 \mathrm{~min}$ at $4000 \mathrm{rpm}(6167 \times \mathrm{g})$, and filtered through acidwashed paper, discarding the liquid phase. The remaining solid phase was then subjected to a desorption procedure, adding $30 \mathrm{~mL}$ of solutions containing $\mathrm{NaNO}_{3} \quad 0.01 \mathrm{M}$ and diverse $\mathrm{HNO}_{3}$ or $\mathrm{NaOH}$ concentrations aiming to provide a wide $\mathrm{pH}$ range, then being different for the various solid samples. All samples were shaken for $24 \mathrm{~h}$, centrifuged for $15 \mathrm{~min}$ at $4000 \mathrm{rpm}(6167 \times \mathrm{g})$, and filtered through acidwashed paper. The resulting liquid was analyzed for $\mathrm{pH}$, DOC, and Cr(VI). Desorbed Cr(VI) was calculated as the difference between the amount retained in the sorption phase and that released to the equilibrium solution in the desorption phase, and it was expressed as percentage of the total amount adsorbed.

\subsubsection{Fractionation of the $\mathrm{Cr}(\mathrm{VI})$ adsorbed at three different incubation times}

Samples corresponding to the sorbent materials (Table 1) were added with a $\mathrm{NaNO}_{3} \quad 0.01 \mathrm{M}$ solution containing $100 \mathrm{mg} \mathrm{L}^{-1} \mathrm{Cr}$ (VI) (1: 10 solid: solution ratio); then they were shaken for $24 \mathrm{~h}$ and filtered. The resulting liquid was analyzed for $\mathrm{pH}$, DOC, and $\mathrm{Cr}(\mathrm{VI})$. Finally, fractionation of the adsorbed $\mathrm{Cr}(\mathrm{VI})$ was carried out using the European Community Bureau of Reference (BCR) procedure modified by Rauret et al. (1999). The fractionation was performed after $24 \mathrm{~h}, 1$ week, and 1 month. The resulting fractions were acid-soluble fraction, reducible fraction, oxidizable fraction, and residual fraction (all of them measured, not estimated).

\subsubsection{Data analysis}

The statistical package SPSS 19.0 (IBM, USA) was used to check data for normality. Then, Pearson correlations were calculated.

Finally, $\mathrm{Cr}(\mathrm{VI})$ sorption data were fitted to the Freundlich model (Eq. 1). Fitting to the Langmuir model was not possible due to estimation errors being too high.

The formulation of the Freundlich equation is as follows:

$q_{\mathrm{e}}=K_{\mathrm{F}} \cdot C_{\mathrm{e}}^{n}$,

where $q_{\mathrm{e}}\left(\mathrm{mg} \mathrm{kg}^{-1}\right)$ is the ion sorption per unit of mass for the adsorbent, $C_{\mathrm{e}}\left(\mathrm{mg} \mathrm{L}^{-1}\right)$ is the equilibrium concentration of the dissolved $\mathrm{Cr}, K_{\mathrm{F}}\left(\mathrm{L}^{n} \mathrm{~g}^{-1} \mathrm{mg}^{(1-n)}\right)$ is a constant related to the sorption capacity, and $n$ (dimensionless) is a constant related to the sorption intensity.

\section{Results and discussion}

\subsection{Characterization of the solid materials used}

Table 2 shows data of some basic characteristics of the solid materials used in this study.

\subsection{Sorption/desorption when different $\operatorname{Cr}(\mathrm{VI})$ concentrations were added}

\subsubsection{Sorption}

Figure 1 shows that $\mathrm{Cr}(\mathrm{VI})$ sorption increased with $\mathrm{Cr}(\mathrm{VI})$ concentration in the equilibrium solution, which was directly related to the increase in the $\mathrm{Cr}(\mathrm{VI})$ concentration added. The same behavior was observed by Fernández-Pazos et al. (2013) using mussel shell, pyritic material, forest soil and slate-processing fines; by Rawajfih and Nsour (2008) using Phragmites australis biomass; and by Vinodhini and Nilanjana (2009) using various bio-adsorbent materials. In the present work, the maximum sorption corresponded to the pyritic material (between 97.1 and $98.7 \%$ of the initial amount added $)$, significantly higher $(p<0.005)$ than that 
Table 2. General characteristics of the solid materials (average values for three replicates, with coefficients of variation always $<5 \%$ ).

\begin{tabular}{|c|c|c|c|c|}
\hline & Granitic material & Forest soil & Mussel shell & Pyritic material \\
\hline Sand $(\%)$ & 60.00 & 65.00 & 99.53 & 67.00 \\
\hline Silt $(\%)$ & 17.00 & 20.00 & 0.34 & 14.00 \\
\hline Clay (\%) & 23.00 & 15.00 & 0.13 & 19.00 \\
\hline $\mathrm{C}(\%)$ & 0.11 & 4.22 & 11.43 & 0.26 \\
\hline $\mathrm{N}(\%)$ & 0.04 & 0.33 & 0.21 & 0.04 \\
\hline $\mathrm{pH}_{\mathrm{H}_{2} \mathrm{O}}$ & 5.72 & 5.65 & 9.39 & 2.97 \\
\hline $\mathrm{pH}_{\mathrm{KCl}}$ & 3.69 & 4.70 & 9.04 & 2.58 \\
\hline $\mathrm{Ca}_{\mathrm{c}}\left(\mathrm{cmol} \mathrm{kg}^{-1}\right)$ & 0.18 & 4.37 & 24.75 & 0.36 \\
\hline $\operatorname{Mg}_{\mathrm{c}}\left(\mathrm{cmol} \mathrm{kg}^{-1}\right)$ & 0.13 & 0.66 & 0.72 & 0.29 \\
\hline $\mathrm{Na}_{\mathrm{c}}\left(\mathrm{cmol} \mathrm{kg}^{-1}\right)$ & 0.27 & 0.33 & 4.37 & 0.14 \\
\hline $\mathrm{K}_{\mathrm{c}}\left(\mathrm{cmol} \mathrm{kg}^{-1}\right)$ & 0.31 & 0.60 & 0.38 & 0.24 \\
\hline $\mathrm{Al}_{\mathrm{c}}\left(\mathrm{cmol} \mathrm{kg}^{-1}\right)$ & 1.63 & 1.92 & 0.03 & 2.86 \\
\hline $\mathrm{e}-\mathrm{CEC}\left(\mathrm{cmol} \mathrm{kg}^{-1}\right)$ & 2.53 & 7.88 & 30.26 & 3.89 \\
\hline Al-saturation ( \%) & 64.55 & 24.41 & 0.11 & 73.68 \\
\hline $\mathrm{P}_{\text {Olsen }}\left(\mathrm{mg} \mathrm{kg}^{-1}\right)$ & 2.56 & 28.80 & 54.17 & 8.80 \\
\hline $\mathrm{Ca}_{\mathrm{T}}\left(\mathrm{mg} \mathrm{kg}^{-1}\right)$ & $<0.01$ & 709 & 280168 & 603 \\
\hline $\operatorname{Mg}_{\mathrm{T}}\left(\mathrm{mg} \mathrm{kg}^{-1}\right)$ & 355 & 831 & 981 & 8384 \\
\hline NaT $\left(\mathrm{mg} \mathrm{kg}^{-1}\right)$ & 102 & 515 & 5174 & 412 \\
\hline $\mathrm{K}_{\mathrm{T}}\left(\mathrm{mg} \mathrm{kg}^{-1}\right)$ & 1434 & 1544 & 202 & 3186 \\
\hline $\mathrm{Mn}_{\mathrm{T}}\left(\mathrm{mg} \mathrm{kg}^{-1}\right)$ & 24 & 93 & 34 & 296 \\
\hline $\mathrm{Cu}_{\mathrm{T}}\left(\mathrm{mg} \mathrm{kg}^{-1}\right)$ & 7 & 16 & 7 & 773 \\
\hline $\mathrm{Zn}_{\mathrm{T}}\left(\mathrm{mg} \mathrm{kg}^{-1}\right)$ & 18 & 37 & 8 & 58 \\
\hline $\mathrm{Ni}_{\mathrm{T}}\left(\mathrm{mg} \mathrm{kg}^{-1}\right)$ & 1 & 11 & 8 & 5 \\
\hline $\mathrm{Cd}_{\mathrm{T}}\left(\mathrm{mg} \mathrm{kg}^{-1}\right)$ & $<0.001$ & 0.43 & 0.07 & 0.08 \\
\hline $\mathrm{Cr}_{\mathrm{T}}\left(\mathrm{mg} \mathrm{kg}^{-1}\right)$ & 3 & 18 & 5 & 99 \\
\hline $\mathrm{Co}_{\mathrm{T}}\left(\mathrm{mg} \mathrm{kg}^{-1}\right)$ & 0.4 & 1.4 & 1.0 & 3.1 \\
\hline $\operatorname{AsT}\left(\mathrm{mg} \mathrm{kg}^{-1}\right)$ & 3 & 4 & 1 & 7 \\
\hline $\mathrm{Al}_{\mathrm{T}}\left(\mathrm{mg} \mathrm{kg}^{-1}\right)$ & 5981 & 19660 & 433 & 9624 \\
\hline $\mathrm{Fe}_{\mathrm{T}}\left(\mathrm{mg} \mathrm{kg}^{-1}\right)$ & 3505 & 9486 & 3535 & 135157 \\
\hline $\mathrm{Al}_{\mathrm{O}}\left(\mathrm{mg} \mathrm{kg}^{-1}\right)$ & 1425 & 4275 & 178 & 563 \\
\hline $\mathrm{Al}_{\mathrm{p}}\left(\mathrm{mg} \mathrm{kg}^{-1}\right)$ & 463 & 4163 & 78.7 & 229 \\
\hline $\mathrm{Al}_{\mathrm{op}}\left(\mathrm{mg} \mathrm{kg}^{-1}\right)$ & 963 & 112 & 99.7 & 335 \\
\hline $\mathrm{Al}_{\mathrm{cu}}\left(\mathrm{mg} \mathrm{kg}^{-1}\right)$ & 150 & 868 & 22.9 & 186 \\
\hline $\mathrm{Al}_{\mathrm{pcu}}\left(\mathrm{mg} \mathrm{kg}^{-1}\right)$ & 312 & 3295 & 55.8 & 42.7 \\
\hline $\mathrm{Al}_{\mathrm{la}}\left(\mathrm{mg} \mathrm{kg}^{-1}\right)$ & 137 & 146 & 2.6 & 91.1 \\
\hline $\mathrm{Al}_{\text {cula }}\left(\mathrm{mg} \mathrm{kg}^{-1}\right)$ & 12.8 & 722 & 20.3 & 134 \\
\hline $\mathrm{Fe}_{\mathrm{o}}\left(\mathrm{mg} \mathrm{kg}^{-1}\right)$ & 224 & 2333 & 171 & 41860 \\
\hline $\mathrm{Fe}_{\mathrm{p}}\left(\mathrm{mg} \mathrm{kg}^{-1}\right)$ & 54.3 & 2246 & 37.7 & 625 \\
\hline $\mathrm{Fe}_{\text {op }}\left(\mathrm{mg} \mathrm{kg}^{-1}\right)$ & 170 & 86.9 & 133 & 41235 \\
\hline
\end{tabular}

Element $\mathrm{c}_{\mathrm{c}}$ : concentration in the exchange complex; Element $\mathrm{T}_{\mathrm{T}}$ : total concentration; $\mathrm{Al}_{\mathrm{O}}, \mathrm{Fe}_{\mathrm{o}}$ : extracted with ammonium oxalate; $\mathrm{Al}_{\mathrm{p}}, \mathrm{Fe}_{\mathrm{p}}$ : extracted with sodium pyrophosphate; $\mathrm{Al}_{\mathrm{cu}}$ : extracted with copper chloride; $\mathrm{Al}_{\mathrm{la}}$ : extracted with lanthanum chloride; $\mathrm{Al}_{\mathrm{op}}: \mathrm{Al}_{\mathrm{o}}-\mathrm{Al}_{\mathrm{p}} ; \mathrm{Al}_{\mathrm{pcu}}: \mathrm{Al}_{\mathrm{p}}-\mathrm{Al}_{\mathrm{cu}} ; \mathrm{Al}_{\mathrm{cula}}: \mathrm{Al}_{\mathrm{cu}}-\mathrm{Al}_{\mathrm{la}} ; \mathrm{Fe}_{\mathrm{op}}: \mathrm{Fe}_{\mathrm{o}}-\mathrm{Fe}_{\mathrm{p}}$.

achieved by forest soil (between 22.1 and $86 \%$ ), mussel shell (between 20.9 and $31.2 \%$ ), and the granitic material (between 19.5 and $31.2 \%$ ). The mussel shell amendment (12 $\mathrm{tha}^{-1}$, equivalent to $1.2 \mathrm{~kg} \mathrm{~m}^{-2}$ ) caused $\mathrm{Cr}(\mathrm{VI})$ sorption to reach values between 21 and $86 \%$ on forest soil, whereas $\mathrm{Cr}(\mathrm{VI})$ sorption achieved up to $50 \%$ on granitic material. In a previous work, Fernández-Pazos et al. (2013) found slightly lower $\mathrm{Cr}(\mathrm{VI})$ sorption on pyritic material and mussel shell, whereas sorption was very similar on their forest soil samples.

Significant correlations $(p<0.005)$ were found between the amounts of $\mathrm{Cr}(\mathrm{VI})$ sorbed (in $\mathrm{mg} \mathrm{kg}^{-1}$ ) and total $\mathrm{Fe}(r=$ $0.995)$, Fe extracted with ammonium oxalate $(r=0.993)$, non-crystalline inorganic $\mathrm{Fe}(\mathrm{r}=0.992)$, and $\mathrm{pH}$ in water $(r=$ $-0.900)$, when chromium concentrations of $100 \mathrm{mg} \mathrm{L}^{-1}$ were added to the sorbent materials. Previously, Martin and Kempton (2000) observed that Cr(VI) sorption increased 

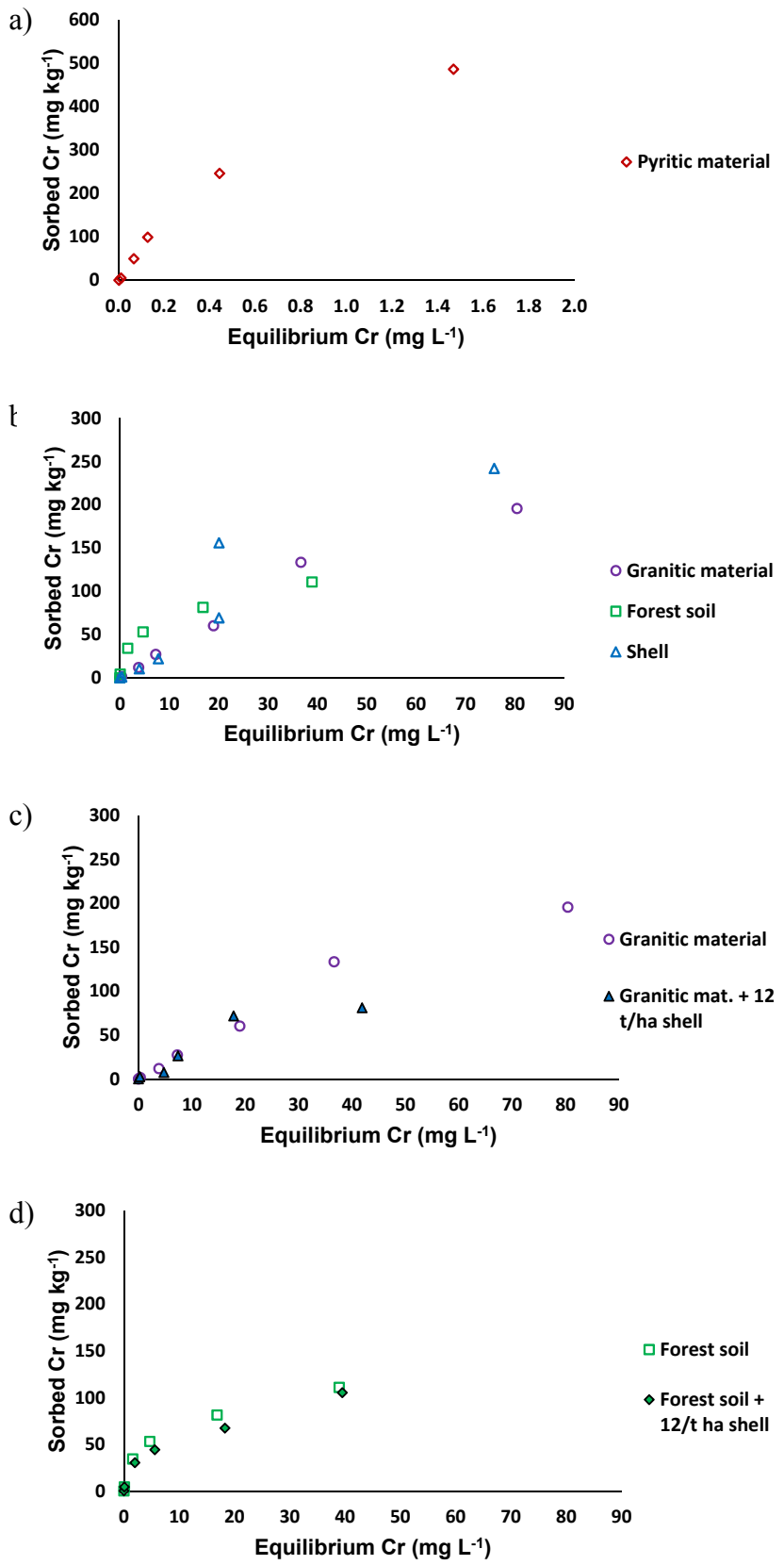

Figure 1. Sorption points corresponding to the pyritic material (a); granitic material, forest soil, and mussel shell (b); granitic material with or without mussel shell (c); and forest soil with or without mussel shell (d). Mean values; triplicate samples with coefficient of variation $<5 \%$.

as a function of $\mathrm{Fe}$ oxide content, whereas Mesuere and Fish (1992) and Weerasooriya and Tobschall (2000) indicated that $\mathrm{Cr}(\mathrm{VI})$ has slow to moderate affinity for $\mathrm{Fe}$ and $\mathrm{Al}$ oxy-hydroxides. These facts are in relation to the high sorption capacity of our pyritic material, characterized by having high $\mathrm{Fe}$ contents and very acid $\mathrm{pH}$; furthermore, a stepwise regression test corroborated the im-
Table 3. Fitting of the various materials to the Freundlich model.

\begin{tabular}{|c|c|c|c|}
\hline & \multicolumn{3}{|c|}{ Freundlich } \\
\hline & $\left.\begin{array}{c}K_{\mathrm{F}} \\
\left(\mathrm{L}^{n} \mathrm{~g}^{-1} \mathrm{mg}\right. \\
(1-n)\end{array}\right)$ & $n$ & $R^{2}$ \\
\hline GM & $7.5 \pm 2.5$ & $0.75 \pm 0.08$ & 0.980 \\
\hline FS & $28.1 \pm 2.0$ & $0.38 \pm 0.02$ & 0.995 \\
\hline $\mathrm{Sh}$ & $10.7 \pm 7.1$ & $0.73 \pm 0.17$ & 0.895 \\
\hline $\mathrm{PM}$ & $381.6 \pm 11.7$ & $0.66 \pm 0.04$ & 0.994 \\
\hline $\mathrm{GM}+\mathrm{Sh}$ & $8.3 \pm 5.2$ & $0.63 \pm 0.19$ & 0.891 \\
\hline $\mathrm{FS}+\mathrm{Sh}$ & $19.9 \pm 2.1$ & $0.45 \pm 0.03$ & 0.993 \\
\hline
\end{tabular}

$p<0.005$; GM: granitic material; FS: forest soil; Sh: mussel shell; PM: pyritic material.

portance of the total $\mathrm{Fe}$ content in $\mathrm{Cr}(\mathrm{VI})$ sorption, explicating $99 \%$ of the variance. In our study, the pyritic material was the one with the highest $\mathrm{Cr}(\mathrm{VI})$ sorption capacity, as well as the lowest $\mathrm{pH}$ (2.97), and a high concentration of amorphous minerals. It is remarkable that this pyritic material had high specific surface and $\mathrm{pH}$-dependent exchange capacity, developing positive charge at acid $\mathrm{pH}$, while chromium was in anionic form $\left(\mathrm{HCrO}_{4}^{-}, \mathrm{CrO}_{4}^{2-}\right.$, and $\mathrm{Cr}_{2} \mathrm{O}_{7}^{2-}$ ). The granitic material showed the lowest $\mathrm{Cr}(\mathrm{VI})$ sorption, which could be related to its low total and noncrystalline Fe contents (Table 2). Correlations $(p<0.005)$ between adsorbed $\mathrm{Cr}(\mathrm{VI})$ and $\mathrm{pH}$ of the solution were positive for unamended $(r=0.701)$ and shell-amended granitic material $(r=0.770)$, and for unamended $(r=0.672)$ and shell-amended forest soil $(r=0.819)$, whereas correlations were negative for mussel shell by itself $(r=-0.994)$ and for pyritic material $(r=-0.424)$. These differences could be due to different mechanisms acting when $\mathrm{Cr}(\mathrm{VI})$ sorption takes place on the various materials: electrostatic bindings, then including the possibility of $\mathrm{OH}^{-}$release and consequent $\mathrm{pH}$ increase when chromium anions adsorb (Arnesen and Krogstad, 1998; Gago et al., 2012), or other mechanisms not including $\mathrm{OH}^{-}$release, such as Van der Waals and $\mathrm{H}$ bindings (Boddu et al., 2003). Furthermore, in the present study DOC values increased as a function of adsorbed $\mathrm{Cr}(\mathrm{VI})$, with significant correlations $(p<0.005)$ for granitic material by itself $(r=0.978)$ or mussel-shell-treated $(r=0.983)$, forest soil by itself $(r=0.905)$ or mussel-shell-treated $(r=0.984)$, mussel shell $(r=0.978)$, and pyritic material $(r=0.973)$, which could be related to the release of organic ions when $\mathrm{Cr}(\mathrm{VI})$ sorption takes place. When added $\mathrm{Cr}(\mathrm{VI})$ concentrations increased, both granitic material and forest soil showed decreasing sorption percentages, thus suggesting progressive saturation of the adsorbent surfaces (Nameni et al., 2008). Maximum sorption was clearly higher for forest soil $(86 \%$ of the initial amount added) than for granitic material (31\%), which could be due to the higher content of organic matter, organo-aluminum complexes, and Alo and Feo in the forest soil. In this respect, Kantar et al. (2008) indicate that 
Table 4. Desorbed $\mathrm{Cr}\left(\mathrm{mg} \mathrm{kg}^{-1}\right.$ and $\%$ of the amount previously retained) when $0,0.5,5,10,25,50$, or $100 \mathrm{mg} \mathrm{L}^{-1} \mathrm{Cr}_{\text {was }}$ previously added to the various materials.

\begin{tabular}{llrrrrrrr}
\hline & & Desorbed & \multicolumn{5}{c}{ Added $\mathrm{Cr}\left(\mathrm{mg} \mathrm{L}^{-1}\right)$} \\
\cline { 4 - 8 } & & $\mathrm{Cr}$ & 0.5 & 5 & 10 & 25 & 50 & 100 \\
\hline $\mathrm{GM}$ & $\mathrm{mg} \mathrm{kg}^{-1}$ & 0.003 & 0.943 & 10.249 & 16.893 & 37.799 & 68.150 & 128.289 \\
& $\%$ & 0 & 61 & 92 & 65.5 & 66 & 55 & 67 \\
$\mathrm{FS}$ & $\mathrm{mg} \mathrm{kg}^{-1}$ & 0.000 & 0.634 & 0.905 & 1.314 & 4.773 & 17.711 & 45.115 \\
& $\%$ & 0 & 15 & 2.6 & 2.5 & 6 & 16 & 21 \\
$\mathrm{PM}$ & $\mathrm{mg} \mathrm{kg}^{-1}$ & 0.018 & 0.040 & 0.213 & 0.401 & 1.335 & 4.015 & 4.722 \\
& $\%$ & 0 & 0.8 & 0.4 & 0.4 & 0.5 & 0.8 & 0.5 \\
$\mathrm{Sh}$ & $\mathrm{mg} \mathrm{kg}-1$ & 0.038 & 0.178 & 2.301 & 4.565 & 11.784 & 29.580 & 52.747 \\
& $\%$ & 0 & 17 & 23 & 26 & 22 & 20 & 23 \\
$\mathrm{GM}+12 \mathrm{t} \mathrm{ha}^{-1} \mathrm{Sh}$ & $\mathrm{mg} \mathrm{kg}^{-1}$ & 0.000 & 0.787 & 2.943 & 9.093 & 21.312 & 30.976 & 61.636 \\
& $\%$ & 0 & 31 & 41 & 35 & 33 & 40 & 29 \\
$\mathrm{FS}+12 \mathrm{tha}^{-1} \mathrm{Sh}$ & $\mathrm{mg} \mathrm{kg}^{-1}$ & 0.000 & 0.626 & 2.276 & 4.560 & 16.198 & 37.978 & 85.178 \\
& $\%$ & 0 & 15 & 8 & 10 & 24 & 36 & 44 \\
\hline
\end{tabular}

GM: granitic material; FS: forest soil; PM: pyritic material; Sh: mussel shell.

some ferric organic compounds facilitate the stabilization of $\mathrm{Cr}(\mathrm{VI})$ in acid to slightly alkaline soils due to the catalytic reduction of $\mathrm{Cr}(\mathrm{VI})$ to $\mathrm{Cr}(\mathrm{III})$.

Sorption data were satisfactory fitted to the Freundlich model through nonlinear regression (Table 3), as other authors found for various bio-sorbents (Cetinkaya-Donmez et al., 1999; Prakasham et al., 1999). Due to the fact that the Freunlich model considers that, theoretically, sorption could be infinite, the fitting to this equation means that sorption maximum would not be easily predictable for these materials.

Significant correlations $(p<0.005)$ were found between the Freundlich constant $K_{\mathrm{F}}$ and $\mathrm{Fe}_{\mathrm{T}}(r=1), \mathrm{Fe}_{\mathrm{op}}(r=1)$, and $\mathrm{Fe}_{\mathrm{o}}(r=0.999)$, making evident the importance of amorphous minerals in $\mathrm{Cr}(\mathrm{VI})$ sorption.

\subsubsection{Desorption}

Table 4 shows that the lowest $\mathrm{Cr}(\mathrm{VI})$ desorption corresponded to the pyritic material $(0.4-0.8 \%)$, whereas mussel shell by itself released between 17 and $26 \%$ of the amounts previously adsorbed. When $12 \mathrm{tha}^{-1}$ mussel shell was added to forest soil, $\mathrm{Cr}(\mathrm{VI})$ desorption increased to between 8 and $44 \%$; however desorption decreased to between 29 and $40 \%$ when the granitic material was amended.

\section{3 $\mathrm{Cr}(\mathrm{VI})$ sorption/desorption as a function of $\mathrm{pH}$}

\subsubsection{Sorption}

With the exception of panel a, Fig. 2 shows an overall increase in $\mathrm{Cr}(\mathrm{VI})$ sorption as a function of decreasing $\mathrm{pH}$ values in the equilibrium solutions. Similarly, different authors have indicated that optimum $\mathrm{pH}$ values for $\mathrm{Cr}(\mathrm{VI})$ sorption are between 1 and 2.5 (Huang and Wu, 1977; Boddu et al., 2003; Mohanty et al., 2006; Rawajfih and Nsour, 2008; Vinodhini and Nilanjana, 2009; Wang et al., 2009), due to a higher density of positive charges on the adsorbent surface, thus facilitating the binding to chromium anions that dominate at these very acid $\mathrm{pH}$ values $\left(\mathrm{HCrO}_{4}^{-}, \mathrm{CrO}_{4}^{2-}\right.$, and $\mathrm{Cr}_{2} \mathrm{O}_{7}^{2-}$ ) (Boddu et al., 2003; Gupta et al., 2001; Ucun et al., 2002). Rawajfih and Nsour (2008), as well as Wang et al. (2009), found that increasing $\mathrm{pH}$ values cause competition between chromium oxyanions and $\mathrm{OH}^{-}$, thus decreasing $\mathrm{Cr}(\mathrm{VI})$ sorption. The pyritic material showed the maximum $\mathrm{Cr}(\mathrm{VI})$ sorption, concretely $50 \mathrm{mg} \mathrm{kg}^{-1}$ (equivalent to $99 \%$ of the initial amount added) at $\mathrm{pH} 3.3$ (Fig. 2a), remaining high for the whole $\mathrm{pH}$ range. The mussel shell retained around $50 \%$ of the initial amount of $\mathrm{Cr}(\mathrm{VI})$ added when it was treated with acid and the solution $\mathrm{pH}$ approached 7; however, the addition of base caused sorption to diminish to $2.3 \mathrm{mg} \mathrm{kg}^{-1}$ (equivalent to $4.5 \%$ ) when $\mathrm{pH}$ increased to 10-12 (Fig. 2b). The granitic material showed increased $\mathrm{Cr}(\mathrm{VI})$ retention at $\mathrm{pH}<3$ (Fig. 2c). The forest soil adsorbed $45.7 \mathrm{mg} \mathrm{kg}^{-1} \mathrm{Cr}(\mathrm{VI})$ (equivalent to $91 \%$ of initial amount added) at $\mathrm{pH}$ 2.97, but it decreased to 19.7 (39\%) after being treated with base, reaching pH 5.7 (Fig. 2d). Although positive charges on variable charge surfaces can explain maximum $\mathrm{Cr}(\mathrm{VI})$ sorption when $\mathrm{pH}<3$, the fact that the pyritic material showed high sorption even when the $\mathrm{pH}$ value was increased could be related to its abundant oxy-hydroxides content, some of them with elevated point of zero charge (Bradl, 2004), as well as related to $\mathrm{Cr}(\mathrm{VI})$ reduction to $\mathrm{Cr}(\mathrm{III})$ in the presence of $\mathrm{S}^{2-}$ and $\mathrm{Fe}^{2+}$, given that $\mathrm{Cr}$ (III) may be precipitated at $\mathrm{pH}$ values between 6 and 11 (Eary and Rai, 1988; Sass and Rai, 1987; Weng et al., 1994). Mussel shell amendment did not cause great changes in the sorbent behavior of the amended materials (Fig. 1); however it provoked a slight $\mathrm{pH}$ increase and slight lowering in $\mathrm{Cr}(\mathrm{VI})$ 
a)

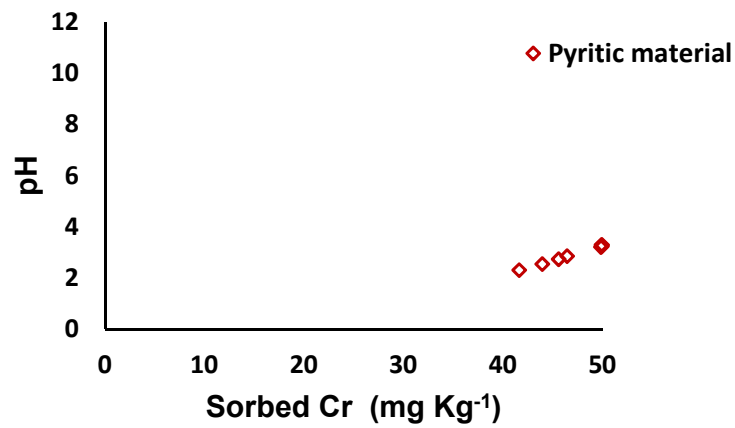

b)

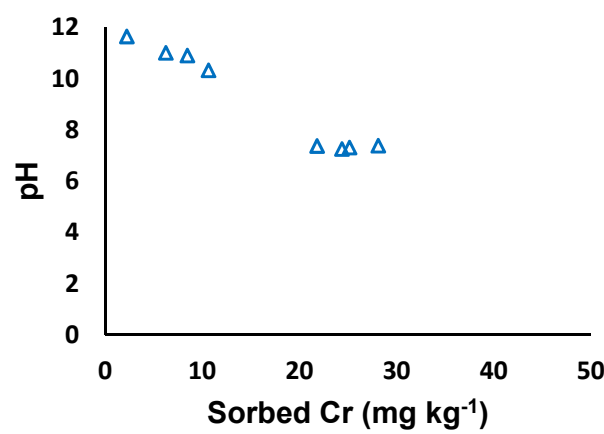

c)

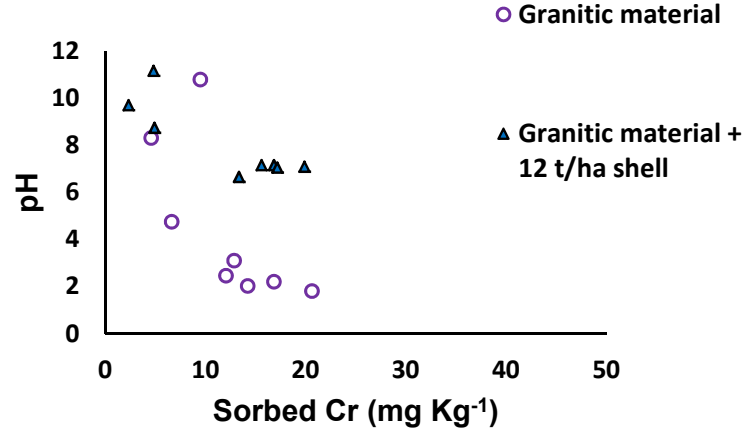

d)

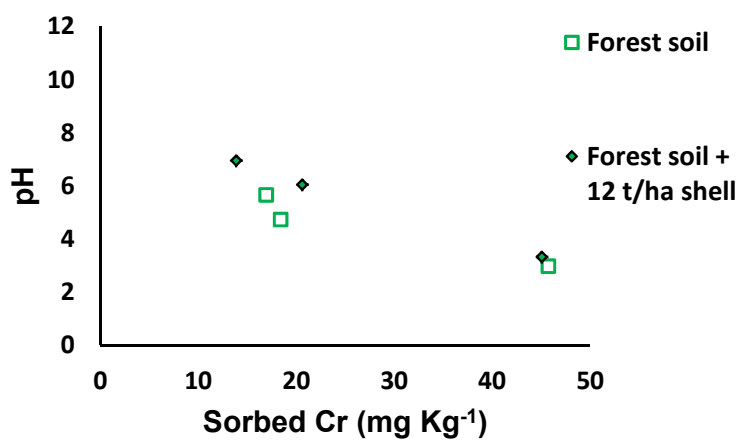

Figure 2. Relation between $\mathrm{pH}$ and sorbed $\mathrm{Cr}\left(\mathrm{mg} \mathrm{kg}^{-1}\right)$ for pyritic material (a), mussel shell (b), amended and unamended granitic material (c), and amended and unamended forest soil (d), after being added with $100 \mathrm{mg} \mathrm{L}^{-1} \mathrm{Cr}$. Mean values; triplicate samples with coefficient of variation $<5 \%$. sorption. But in the case of the forest soil and the granitic material, this amendment increased $\mathrm{Cr}(\mathrm{VI})$ sorption as compared with samples having similar $\mathrm{pH}$ values, which can be attributed to precipitation with carbonates, as signaled by Aziz et al. (2008) studying chromium retention on limestone.

\subsubsection{Desorption}

Figure 3 shows chromium desorption percentage for the various materials after being added with $100 \mathrm{mg} \mathrm{L}^{-1} \mathrm{Cr}(\mathrm{VI})$. Desorption from the pyritic material was very low at $\mathrm{pH}<4$ (Fig. 3a), increasing with $\mathrm{pH}$ up to $51.7 \%\left(478.8 \mathrm{mg} \mathrm{kg}^{-1}\right.$ ) at $\mathrm{pH} 11$, similar to the findings of Muthukrishnan and Guha (2008). Low-crystallinity $\mathrm{Fe}$ and $\mathrm{Al}$ oxy-hydroxides can be positively charged at $\mathrm{pH}<7$ (Parfitt, 1978; Richard and Bourg, 1991), then retaining $\mathrm{CrO}_{4}^{2-}$ (Rai et al., 1989). As $\mathrm{pH}$ decreases, $\mathrm{HCrO}_{4}^{-}$concentration increases, and this anion adsorbs strongly both to low-crystallinity $\mathrm{Fe}$ and $\mathrm{Al}$ oxy-hydroxides and to crystalline $\mathrm{Fe}$ and $\mathrm{Al}$ oxides (Zachara et al., 1989). Cr(VI) desorption from mussel shell was minimum at $\mathrm{pH}$ close to 5.5 (Fig. 3b), clearly increasing at higher and (largely) at lower $\mathrm{pH}$ values. $\mathrm{Cr}(\mathrm{VI})$ released from the granitic material hardly changed as a function of $\mathrm{pH}$ (Fig. 3c), and it was always lower than $15 \%$. $\mathrm{Cr}(\mathrm{VI})$ was almost completely retained in forest soil at $\mathrm{pH}<7$ (Fig. 3d), increasing release with $\mathrm{pH}$ up to a maximum attained at $\mathrm{pH}$ 10.8. Chrysochoou et al. (2010) indicated that the presence of organic matter (as in forest soil) or sulfides (as in pyritic material) facilitates $\mathrm{Cr}(\mathrm{VI})$ reduction to $\mathrm{Cr}(\mathrm{III})$, which can precipitate at $\mathrm{pH}>5$. Avundainayagam et al. (2001) found that $\mathrm{Ca}^{2+}$ can favor $\mathrm{Cr}(\mathrm{VI})$ retention in calcareous soils, acting as a cationic bridge on negatively charged surfaces, or by means of $\mathrm{CaCrO}_{4}$ formation (Perkins and Palmer, 2000). Although without statistical significance, the mussel shell amendment increased $\mathrm{Cr}(\mathrm{VI})$ desorption from the granitic material (Fig. 3c), similarly to the findings of Yolcubal et al. (2007) in a calcareous soil. However, the shell amendment had no effect on $\mathrm{Cr}(\mathrm{VI})$ release from our forest soil (Fig. 3d).

\subsection{Fractionation of the $\mathrm{Cr}(\mathrm{VI})$ adsorbed at three different incubation times}

Figure 4 shows the results corresponding to the fractionation of the adsorbed $\mathrm{Cr}(\mathrm{VI})$, after $24 \mathrm{~h}$ (Fig. 4a), 1 week (Fig. 4b), and 1 month of incubation (Fig. 4c). The soluble fraction (the most labile, Gleyzes et al., 2002; constituted by exchangeable and carbonate-bound forms) was $95 \%$ of the adsorbed $\mathrm{Cr}$ in mussel shell, and $80 \%$ in granitic material, after $24 \mathrm{~h}$ of incubation. The mussel shell amendment caused the soluble fraction in the granitic material to increase to $95 \%$, with parallel diminution of other more stable fractions, probably due to $\mathrm{Cr}$ binding to carbonates present in the shell. Mussel shell and the granitic material (unamended or amended) did not show relevant modifications in the percentage of the solu- 
a)

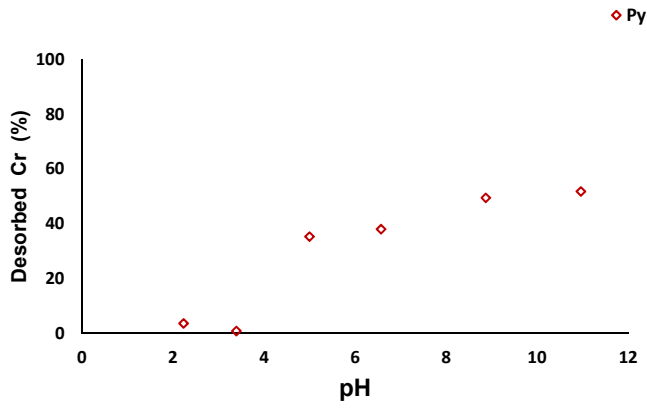

b)

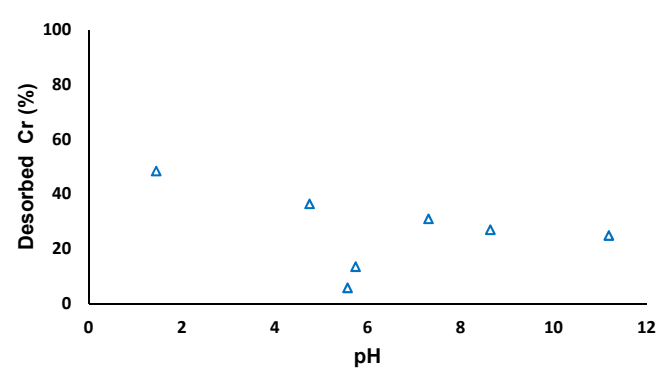

c)

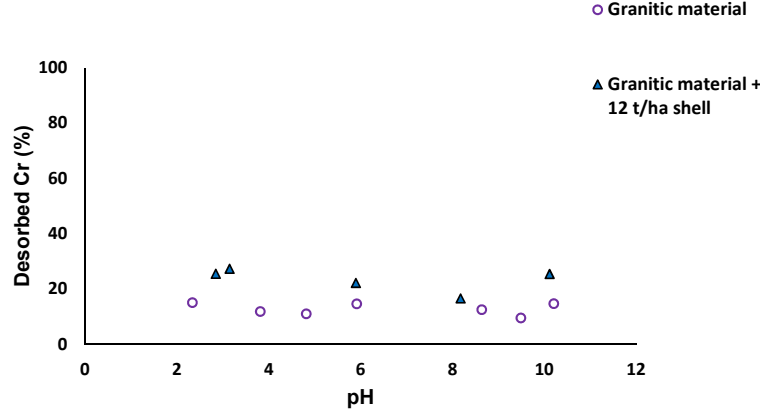

d)

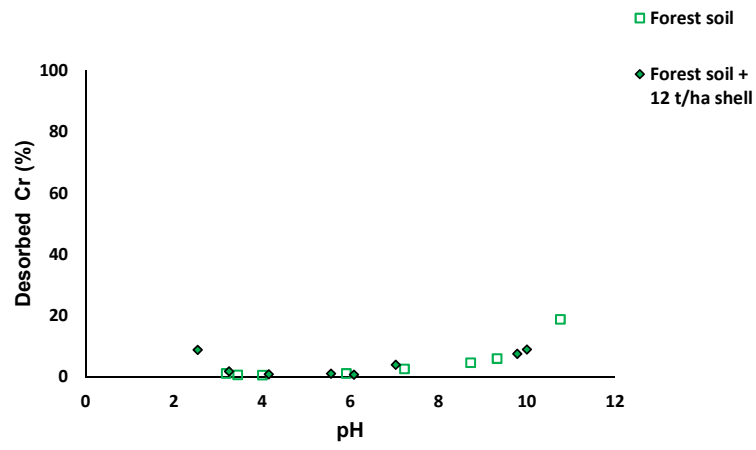

Figure 3. Relation between desorbed $\mathrm{Cr}(\mathrm{VI})(\%)$ and $\mathrm{pH}$ for pyritic material (a), mussel shell (b), amended and unamended granitic material (c), and amended and unamended forest soil (d), after being added with $100 \mathrm{mg} \mathrm{L}^{-1} \mathrm{Cr}$. Mean values; triplicate samples with coefficient of variation $<5 \%$.
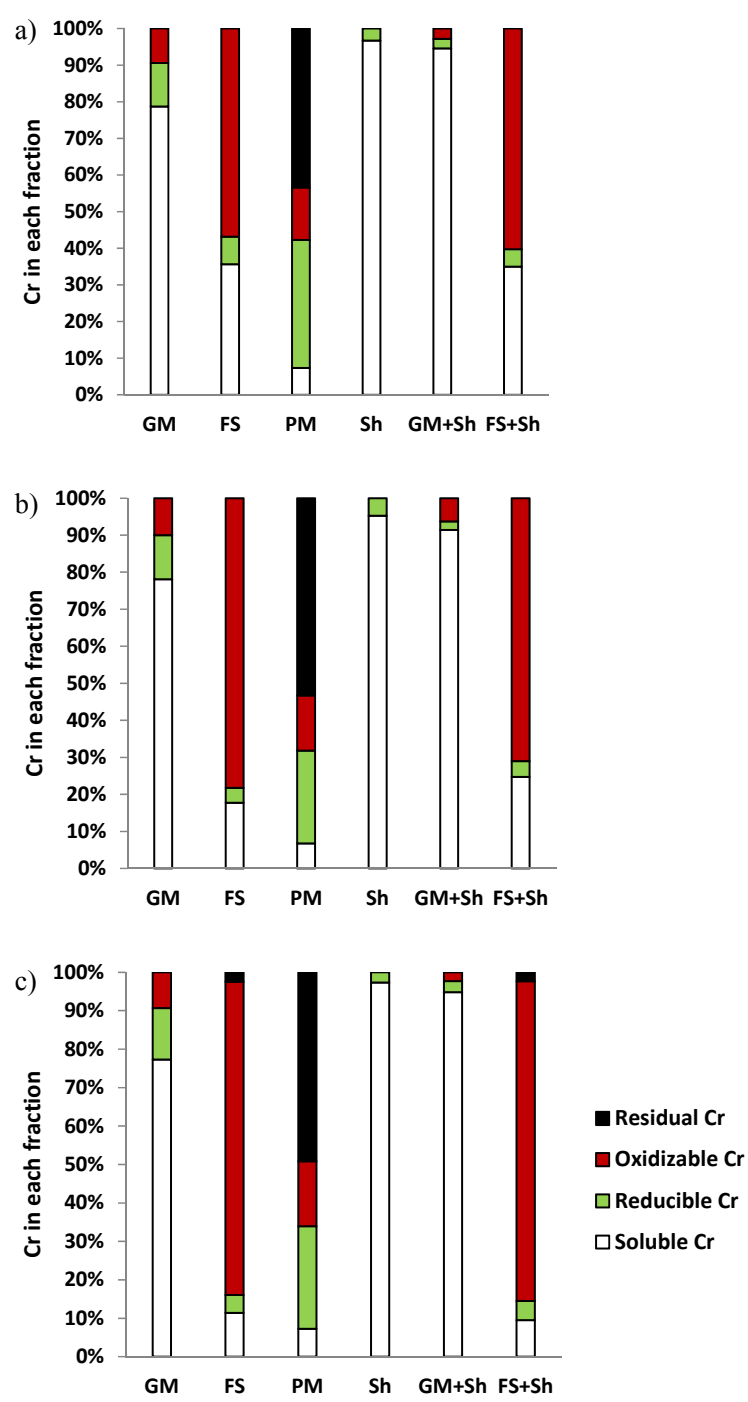

Figure 4. Percentages of the various fractions of chromium sorbed after the addition of $100 \mathrm{mg} \mathrm{L}^{-1} \mathrm{Cr}$ at time 0 , and taken after $24 \mathrm{~h}$ (a), 1 week (b), and 1 month (c) of incubation. GM: granitic material; FS: forest soil; PM: pyritic material; Sh: mussel shell. Mean values; triplicate samples with coefficient of variation $<5 \%$.

ble fraction for more extended periods of incubation (1 week and 1 month). At $24 \mathrm{~h}$ of incubation, the soluble fraction was $35 \%$ for forest soil, and $7 \%$ for the pyritic material. The value did not suffer relevant changes with time for the latter, but in the case of forest soil it decreased to 17 and to $11 \%$ when incubation time was 1 week and 1 month, respectively, due to the increase of a more stable fraction (the oxidizable one, related to organic matter). The mussel shell amendment did not cause remarkable changes in the content of the soluble fraction of forest soil. At $24 \mathrm{~h}$ of incubation, the reducible fraction ( $\mathrm{Cr}$ bound to $\mathrm{Fe}$ and $\mathrm{Al}$ oxides and oxy-hydroxides) represented less than $12 \%$ in mussel shell, as well as in amended and unamended forest soil and granitic material, but more than $35 \%$ in the pyritic material, which can be 
due to its $\mathrm{Fe}_{\mathrm{T}}$ and amorphous $\mathrm{Fe}$ contents (Reddy et al., 1997; Nieto et al., 2008). In fact, in the present study, considering all values, significant $(p<0.005)$ partial correlations were found between $\mathrm{Cr}(\mathrm{VI})$ in the reducible fraction and $\mathrm{Fe}_{\mathrm{op}}(r=0.999), \mathrm{Fe}_{\mathrm{T}}(r=0.998), \mathrm{Fe}_{\mathrm{o}}(r=0.997)$, and $\mathrm{Mn}_{\mathrm{T}}$ $(r=0.964)$. When the incubation time increased to 1 week and 1 month, the reducible fraction decreased in the pyritic material, increasing in parallel the residual fraction (that corresponding to $\mathrm{Cr}$ incorporated to minerals). The mussel shell amendment did not cause relevant changes in the reducible fraction contents. At $24 \mathrm{~h}$ of incubation, the oxidizable fraction (Cr bound to organic matter) represented between 3 and $15 \%$ in mussel shell and the pyritic and granitic materials; however it was $55 \%$ in forest soil, which had higher organic matter content. When incubation time increased, $\mathrm{Cr}(\mathrm{VI})$ in the oxidizable fraction also increased in the forest soil, reaching $80 \%$, whereas that in the soluble fraction (the most labile one) decreased. At $24 \mathrm{~h}$ of incubation, the residual fraction was quantitatively the most important in the pyritic material, representing $40 \%$ of the adsorbed $\mathrm{Cr}(\mathrm{VI})$, and it increased to $50 \%$ when incubation lapsed 1 week.

\section{Conclusions}

The pyritic material showed the highest $\mathrm{Cr}(\mathrm{VI})$ retention capacity among the solid substrates studied, while the lowest corresponded to the granitic material. The forest soil presented high sorption potential when $\mathrm{pH}$ was acid and the $\mathrm{Cr}(\mathrm{VI})$ concentration added was $<10 \mathrm{mg} \mathrm{L}^{-1}$. When the concentrations added were high $\left(50-100 \mathrm{mg} \mathrm{L}^{-1}\right)$, certain saturation of the adsorbent surfaces became apparent, although $\mathrm{Cr}(\mathrm{VI})$ release was low in the wide $\mathrm{pH}$ range studied. $\mathrm{Cr}(\mathrm{VI})$ retention was more pronounced at very acid $\mathrm{pH}$, while increasing $\mathrm{pH}$ values favored its release. Mussel shell showed limited $\mathrm{Cr}(\mathrm{VI})$ retention capacity, and it did not cause marked changes in $\mathrm{Cr}(\mathrm{VI})$ sorption when used as an amendment on forest soil and granitic material. Sorption curves fitted satisfactory to the Freundlich model. The soluble $\mathrm{Cr}(\mathrm{VI})$ fraction was dominant in the mussel shell and in the unamended and amended granitic material, whereas more stable fractions dominate in the pyritic material (residual fraction) and in the forest soil (oxidizable fraction).

Acknowledgements. This study was funded by the Ministerio de Economía y Competitividad (Government of Spain), grant numbers CGL2012-36805-C02-01-02.

Edited by: A. Jordán

\section{References}

Álvarez, E., Fernández-Sanjurjo M. J., Núñez, A., Seco, N., and Corti, G.: Aluminium fractionation and speciation in bulk and rhizosphere of a grass soil amended with mussel shells or lime, Geoderma, 173-174, 322-329, 2013.

Alves, M. M, González-Beça, C. G., Guedes-de-Carvalho, R., Castanheira, J. M., Sol-Pereira M. C., and Vasconcelos, L. A. T.: Chromium removal in tannery wastewaters "polishing" by Pinus sylvestris bark, Water Res., 27, 1333-1338, 1993.

Arnesen, A. K. M. and Krogstad, T.: Sorption and desorption of fluoride in soil polluted from the aluminium smelter at Ardal in Western Norway, Water Air Soil Poll., 103, 357-373, 1998.

Avundainayagam, S., Naidu, R., Kookana, R. S., Alston, A. M., McClure, S. and Smith, L. H.: Effects of electrolyte composition on chromium desorption in soils contaminated by tannery waste, Aust. J. Soil Res., 39, 1077-1089, 2001.

Aziz, H. A., Adlan, M. N., and Ariffin, K. S.: Heavy metals (Cd, $\mathrm{Pb}, \mathrm{Zn}, \mathrm{Ni}, \mathrm{Cu}$ and $\mathrm{Cr}(\mathrm{III})$ ) removal from water in Malaysia: Post treatment by high quality limestone, Bioresource Technol., 99, 1578-1583, 2008.

Blázquez, G., Hernáinz, F., Calero, M., Martín-Lara, M. A., and Tenorio, G.: The effect of $\mathrm{pH}$ on the biosorption of $\mathrm{Cr}$ (III) and Cr (VI) with olive stone, Chem. Eng. J., 148, 473-479, 2009.

Boddu, V. M., Abburi, K., Talbott, J. L., and Smith, E. D.: Removal of hexavalent chromium from wastewater using a new composite chitosan biosorbent, Environ. Sci. Technol., 37, 4449-4456, 2003.

Bradl, H. B.: Adsorption of heavy metal ions on soils and soils constituents, J. Colloid Interf. Sci., 277, 1-18, 2004.

Cetinkaya-Donmez, G., Aksu, Z., Ozturk, A., and Kutsal, T.: A comparative study on heavy metal biosorption characteristics of some algae, Process. Biochem., 34, 885-892, 1999.

Chrysochoou, M., Ferreira, D. R., and Johnston, C. P .: Calcium polysulfide treatment of $\mathrm{Cr}(\mathrm{VI})$-contaminated soil, J. Hazard. Mat., 179, 650-657, 2010.

Di, Z. C., Ding, J., Peng, X. J., Li, Y. H., Luan, Z.-K., and Liang, J.: Chromium adsorption by aligned carbon nanotubes supported ceria nanoparticles, Chemosphere, 62, 861-865, 2006.

Duran, C., Ozdes, D., Gundogdu, A., Imamoglu, M., and Senturk, H. B.: Tea-industry waste activated carbon, as a novel adsorbent, for separation, preconcentration and speciation of chromium, Anal. Chim. Acta, 688, 75-83, 2011.

Eary, L. L. and Rai, D.: Chromate removal from aqueous wastes by reduction with ferrous iron, Environ. Sci. Technol., 22, 676-83, 1988.

Fernández-Pazos, M. T., Garrido-Rodriguez, B., Nóvoa-Muñoz, J. C., Arias-Estévez, M., Fernández-Sanjurjo, M. J., NúñezDelgado, A., and Álvarez, E.: Cr(VI) Adsorption and Desorption on Soils and Biosorbents, Water Air Soil Poll., 224, 1366, 2013.

Fiol, N., Escudero, C., and Villaescusa, I.: Re-use of exhausted ground coffee waste for $\mathrm{Cr}(\mathrm{VI})$ sorption, Separation Sci. Technol., 43, 582-596, 2008.

Gago, C., Romar, A., Fernández-Marcos, M. L., and Álvarez, E.: Fluorine sorption by soils developed from various parent materials in Galicia (NW Spain), J. Colloid Interf. Sci., 374, 232-236, 2012.

Gleyzes, C., Sylvaine, T., and Astruc, M.: Fractionation studies of trace elements in contaminated soils and sediments: a review of 
sequential extraction procedures, Trends Anal. Chem., 21, 451467, 2002.

Gupta, V. K. and Rastogi, A.: Sorption and desorption studies of chromium(VI) from nonviable cyanobacterium Nostoc muscorum biomass, J. Hazard. Mat., 154, 347-354, 2008 a.

Gupta, V. K. and Rastogi, A.: Equilibrium and kinetic modelling of cadmium(II) biosorption by nonliving algal biomass Oedogonium sp from aqueous phase, J. Hazard. Mat., 153, 759-766, 2008b.

Gupta, V. K., Shrivastava, A. K., and Jain, N.: Biosorption of Chromium (VI) from aqueous solutions by green algae Sirogyra species, Water Res., 35, 4079-4085, 2001.

Huang, C. P. and Wu, M. H.: The removal chromium (VI) from dilute aqueous solution by activated carbon, Water Res., 11, 673679, 1977.

Kamprath, E. J.: Exchangeable aluminium as a criterion for liming leached mineral soils, Soil Sci. Soc. Am. P., 34, 252-254, 1970.

Kantar, C., Cetin, Z., and Demiray, H.: In situ stabilization of chromium(VI) in polluted soils using organic ligands: The role of galacturonic, glucuronic and alginic acids, J. Hazard. Mat., 159, 287-293, 2008.

Lilli, M. A., Moraetis, D., Nikolaidis, N. P., Karatzas, G. P., and Kalogerakis, N.: Characterization and mobility of geogenic chromium in soils and river bed sediments of Asopos basin, J. Hazard. Mat., 281, 12-19, 2015.

Mesuere, K. and Fish, W.: Chromate and oxalate adsorption on goethite 1 Calibration of surface complexation models, Environ. Sci. Technol., 26, 2357-2364, 1992.

Mohanty, K., Jha, M., Meikap, B. C., and Biswas, M. N.: Biosorption of $\mathrm{Cr}(\mathrm{VI})$ from aqueous solutions by Eichhornia crassipes, Chem. Eng. J., 117, 71-77, 2006.

Muthukrishnan, M. and Guha, B. K.: Effect of $\mathrm{pH}$ on rejection of hexavalent chromium by nanofiltration, Desalination, 219, 171$178,2008$.

Nameni, M., Alavi, M. R., and Arami, M.: Adsorption of hexavalent chromium from aqueous solutions by wheat bran, Int. J. Environ. Sci. Techol., 5, 161-168, 2008.

Nieto, A. M., Soriano, J. J., and García-Delgado, R. A.: Changes in chromium distribution during the electrodialytic remediation of a Cr (VI)-contaminated soil, Environ. Geochem. Health, 30, 153-157, 2008.

Olsen, S. R. and Sommers, L. E.: Phosphorus, in: Methods of Soil Analysis - Part 2: Chemical and Microbiological Properties, ASA, Madison, USA, 403-430, 1982.

Parfitt, R. L.: Anion adsorption by soils and soil materials, Adv. Agron., 30, 1-50, 1978.

Park, D., Yun, Y., Jo, J., and Park, J.: Biosorption Process for Treatment of Electroplating Wastewater Containing $\mathrm{Cr}(\mathrm{VI})$ : Laboratory-Scale Feasibility Test, Ind. Eng. Chem. Res., 45, 5059-5065, 2006.

Perkins, R. B., and Palmer, C. D.: Solubility of $\mathrm{Ca}_{6}[\mathrm{Al}(\mathrm{OH}) 6] 2\left(\mathrm{CrO}_{4}\right) 3.26 \mathrm{H}_{2} \mathrm{O}$, the chromate analog of ettringite, 5-75 ${ }^{\circ} \mathrm{C}$, Appl. Geochem., 15, 1203-1218, 2000.
Prakasham, R. S., Merrie, J. S., Sheela, R., Saswathi, N., and Ramakrisha, S. V.: Biosorption of chromium(VI) by free and immobilized Rhizopus arrhizus, Environ. Pollut., 104, 421-427, 1999.

Rai, D., Eary, L. E., and Zachara, J. M.: Environmental chemistry of chromium, Sci. Total Environ., 86, 15-23, 1989.

Rauret, G., López-Sánchez, J. F., Sahuquillo, A., Rubio, R., Davidson, C. M., Ure, A. M., and Quevauviller, J.: Improvement of the $\mathrm{BCR}$ three step sequential extraction procedure prior to the certification of new sediment and soil reference materials, J. Environ. Monitor., 1, 57-61, 1999.

Rawajfih, Z. and Nsour, N.: Thermodynamic analysis of sorption isotherms of chromium (VI) anionic species on reed biomass, J. Chem. Thermodyn., 40, 846-851, 2008.

Reddy, K. and Chinthamreddy, S.: Electrokinetic remediation of heavy metal contaminated soils under reducing environments, Waste Manage., 55, 203-503, 1997.

Richard, F. C. and Bourg, A. C. M.: Aqueous geochemistry of chromium: a review Water Res., 25, 807-816, 1991.

Sass, B. M. and Rai, D.: Solubility of amorphous chromium(III)iron(III) hydroxide solid solution, Inorg. Chem., 26, 2228-2232, 1987.

Schiever, S. and Volesky, B.: Modelling of the proton-metal ion exchange in biosorption, Environ. Sci. Technol., 29, 3049-3058, 1995.

Schmuhl, R., Krieg, H. M., and Keizer, K.: Adsorption of Cu(II) and $\mathrm{Cr}(\mathrm{VI})$ ions by chitosan: Kinetics and equilibrium studies, Water SA, 24, 1-8, 2001.

Ucun, H., Bayhan, Y. K., Kaya, Y., Cakici, A., and Algur, O. F.: Biosorption of chromium (VI) from aqueous solution by cone biomass of Pinus sylvestris, Bioresource Technol., 85, 155-158, 2002.

Vinodhini, V. and Nilanjana, D.: Biowaste materials as sorbents to remove chromium (VI) from aqueous environment, a comparative study, J. Agr. Biol. Sci., 4, 19-23, 2009.

Wang, X. S., Li, Z. Z., and Tao, S. R.: Removal of chromium (VI) from aqueous solution using walnut hull, J. Environ. Manage., 90, 721-729, 2009.

Weerasooriya, R. and Tobschall, H. J.: Mechanistic modeling of chromate adsorption onto goethite, Colloid. Surface A, 162, 167$175,2000$.

Weng, C. H., Huang, C. P., Allen, H. E., Cheng. A. H.-D., and Sanders, P. F.: Chromium leaching behavior in soil derived from chromite ore processing waste, Sci. Total Environ., 154, 71-86, 1994.

Yolcubal, I. and Nihat, H. A.: Retention and Transport of Hexavalent Chromium in Calcareous Karst Soils, Turkish J. Earth Sci., 16, 363-379, 2007.

Zachara, J. M., Ainsworth, C. C., Cowan, C. E., and Resch, C. T.: Adsorption of chromate by subsurface soil horizons, Soil Sci. Soc. Am. J., 53, 418-428, 1989. 